\title{
The Formation of Regional Identity \\ in the Space of the Siberian Region \\ (on the Material of Motherland Concept Analysis)
}

\author{
Anastasia M. Obmorokova and Natalia O. Nemaeva* \\ Siberian Federal University \\ 79 Svobodny, Krasnoyarsk, 660041, Russia
}

Received 03.12.2015, received in revised form 04.12.2015, accepted 28.12.2015

The article below is a general review and it is dedicated to a regional identity phenomenon and sociocultural features of its formation. The key to understanding processes of different types of identities formation is carrying out researches on national and ethnic cultural processes. The present article gives a brief analytical and critical review of scientific works and articles of other authors written on the aforesaid topic. The subject of ethnocultural identity influence on the formation of national self-consciousness is revealed. The main method is critical analytics of the modern researches on the problem of regional identification and self-identification. The emphasis is put on the researches which focus on the Siberian regions of the Russian Federation. The modern problemacy of the ways of regional identity and self-identity formation reveals through the soft power of the cultural policy and the smart power of the scientific researches and creative projects of those who live and work in a specific region. This soft power favours construction of images, constants and concepts in a cultural space through preservation of national traditions and customs and its transmission to spectators via works of art and culture. One of the concepts connected with socialization, adoption and basic meanings is the concept Motherland. The article is focused on the image of the small homeland in the consciousness of the people of the Siberian region.

Keywords: region, identity, Motherland, Siberia, culture, regional studies, concept, art culture.

DOI: 10.17516/1997-1370-2016-9-2-406-418.

Research area: culture studies.

\section{Introduction}

Worldwide interest in the concepts of identification and identity has been increasing during last decades (Brejda et al., 2000; Cheng et al., 2005; Galkin, 2014; Il'beikina et al., 2015; Koptseva \& Kirko, 2014a; Paasi, 2013; Prokkola et al., 2015; Raagmaa, 2002; Terada, 2003; Zamaraeva et al., 2015, etc.). Identity has become a prizm, through which major features of modern life are overlooked, evaluated and studied. Russian researches have already accumulated certain experience in studying regional cultural identities. Besides, studying the mechanisms of Russian cultural identity in general is also in process. "Studying the mechanisms of transformation of ethnic and

(c) Siberian Federal University. All rights reserved

* Corresponding author E-mail address: jolly_rogue@mail.ru 
cultural (ethnocultural) identity into national identity has great significance for the polyethnic cultural society of modern Russia" (Antonova, 2010). A number of scientists argue that the key to understanding processes of different types of identities formation is carrying out researches on national and ethnic cultural processes (Assmann \& Czaplicka, 1990; Friedman, 1994; Grossberg, 1996; Hall, \& Du Gay, 1996; Kistova et al., 2014a; Koptseva \& Kirko, 2015; Reznikova, 2015; Santos, 2015; Sitnikova, 2014; Ward \& Searle, 1991; Wrobel \& Steiner, 1997, etc).

Nowadays there are three main research approaches to understanding the origins of ethnos and ethnicity. Social constructivism's approach is connected with the postulate which says that ethnicity is a social construct (ethnos is not a given, it is a result of a specific activity). On the contrary, primordialism (ethnos as initial and unchangeable unity of people bound by blood has permanent features) is based on the axiom which says that ethnicity is a natural social quality, an attribute of social groups, a primordial (fundamental and inborn) social constant. The third approach is a blend of primordialism and social constructivism which claims that ethnicity is the result of deliberate political influence on social and cultural processes in particular elitist social subjects. That is why ethnicity is historically temporal, its historical time is predetermined by political (ideologically expressed) will of economic elitist subjects. Given approach, being a mix of primordialistic and social constructivists' ideas as a way of understanding ethnicity, was widespread in the mid 70s in the Western ethnology.

\section{Ethnocultural identity}

\section{in Alexander G. Dugin's conception}

The conception of ethno-symbolism, developed by a British sociologist and philosopher Anthony Smith, says that nation is connected with ethnos as with natural social unity, but nation itself is an artificial construct. Ethnocultural identity inevitably exists in the national construct, Anthony Smith claims. "It remains not only in the artificially supported national collective consciousness, but also in the collective unconsciousness, usually in socially negative forms. Ethnic identity dissolves in a nation, it is forced out through various social phobias: migrant phobia, xenophobia, racism (including biological and/or cultural), nazism, chauvinism, etc.'(Koptseva, 2014a).

Philosopher and sociologist prof. Alexander G. Dugin bases his original conception on the Gilbert Durand's sociology of depth and correlates ethnos - folk - nation within the frameworks of structural sociology (Drozdova, 2011; Dugin, 2010, 2011). He introduces the notion of mythos and logos which are the parts of the ethnos folk - nation triad. Ethnos is a pure myth; during formation of a state folk becomes identical with logos. "Ethnos is a limited unity connected by the common character of the myth. There cannot exist two ethnic groups with identical myths. Elements of myths can be similar but their combination is unique for every ethnos" (Drozdova, 2011). The basic feature of ethnos is that the processes taking their courses in the minds and hearts of an ethnic community are similar. Logos introduces a fundamentally new dimension into an ethnic life. Structures of consciousness and unconsciousness have more complex relations than myth has. The content of myth doesn't necessarily pass to logos of a folk. Thus a folk is an ethnos blessed with logos. "The transformation of an ethnos into a folk is not a quantitative, economic or political process. It is a deep philosophical phenomenon when something shifts in a myth and it transforms into something fundamentally different - into logos" (Drozdova, 2011).

In its turn nation is a purely modern phenomenon. The origin of the nation is related to 
a notion state. Nation is connected with ethnos on a genetic level as it originates in ethnos. "However, with its formation nation gets free from what was its origin" (Drozdova, 2011). Nation-state distinctively identifies itself with logos. It can be clearly seen in the influence of the state and its introduction of certain social restrictions and standards: standard national language, common law, the state artificially unites several ethnic groups into a larger homogeneous ones, etc.

Ethnos is a simple community naturally connected with the territory it lives in and united by common morality, customs and symbolic system. Customs transformed into traditions, cultural features, which distinct one particular group of people from the others, undoubtedly indicate the relation to ethnos. They constitute the definition of ethnos.

"Ethnos percepts space simply, natural and continuous (there is no border between ethnos and the space of a living world). It is imprinted in numerous legends and myths, in which land, rivers, forests, fields and mountains appear as animate creatures (spirits, gods) kindred to people or represent their ancestors. Hence the idea of home places" (Dugin, 2010). Practically these places are related to a land where a person was born but on the deeper level they represent ties of consanguinity as a feature of ethnos. Ethnos percepts the space as its extension. Thus the space becomes ethnic as an inner part of the life of ethnos.

Alexander G. Dugin proposes an integrated research approach and introduces the term cultural primordialism. He finds it possible to relate the given term to such social unity as ethnos. The researcher determines the social unity of nation as the second derivation of ethnos and he supposes that contemporary modernist theories and ideas of social constructivism are acceptable and efficient when it comes to his perception of the nation concept (Koptseva, 2014a).
Thus, the integration of social constructivism and primordialism is seen as an effective conceptual strategy for studying effective patterns of transformation of the ethnic identification and self-identification processes into national ones. The given integrated conceptual strategy allows to explain the nature of the social constructivism and the ways of how ethnicity transforms into nationality.

National identity can only exist on the basis of social policy connected with the design of a national ideology through cultural policy with regional identities obtaining their new forms and emotional features. The phenomenon of regional identity is a matter of great interest for researchers as it is a significant part of the formation of a region as a specific social-political and institutional space (Collier \& Thomas, 1988; Gerasimov, 2013; Khrapova, 2011; Mansurov, 2011; Shusharina, 2013; Smolicz, 1991; Szabo \& Ward, 2015; Ting-Toomey et al., 2000).

\section{Regional identity in modern Russia}

According to T. Z. Mansurov's article "Theoretic and methodological approaches to the problem of regional identity in political sciences" identity has a multilevel nature. The tendency to describe identity as a multilevel phenomenon of a sociopolitical life can be traced in research works of a number of scientists, philosophers, sociologists, psychologists, cultural and political scientists of the XIX and XX centuries. Dividing identity into levels T.Z. Mansurov adheres to the idea of the Russian researchers M. Kh. Farukshin and O.I. Zaznaev who propose three levels of the identity analysis: "on the individual (microsocial level) a person identifies him or herself with the most significant people in his or her life (family, friends, colleagues, etc.); on the social level - with certain social groups (according to gender, age, occupation, etc.); on the macrosocial level - with 
the most wide categories such as ethnos, nation, culture, religion or politics" (Mansurov, 2013). One of the peculiarities of the Russian society's consciousness is the identity crisis which has recently engulfed Russia. The reasons of the identity crisis are connected with the destruction of the Soviet Union identity's values and the loss of the connection with the traditions of the Russian state.

As it was mentioned before, the problems of the national ideology formation and of the national identity can be solved if we focus on local problems with regional identities, which have their specific features. Today the problem of the regional identity and self-identification patterns has the leading position in discussions and researches on social consciousness. Besides, regional identity is considered an instrument of solution of political problems connected with political activation of people who live in a certain region. Scientists and researchers regard cultural policy (soft power) and scientific researches (smart power) as the instruments for regional identity and self-identification formation.

In her research article "Cultural influence as a component of the soft power" D.A. Zvyagina comes to a conclusion that the analysis of how culture influences world politics and international relationships is indispensible, she also introduces types of identities. Although the concept of soft power, which was introduced by a political scientist Joseph S. Nye, has already deeply entrenched in the political science discourse and its meaning is to "convince others to want something you want yourself". However, still there is no common approach neither to the definition of the soft power, nor to its nature (Zvyagina, 2012). D.A. Zvyagina comes to a conclusion that the phenomenon of soft power is a mix of economic, political and cultural influence. In her research she focuses on the third component - cultural influence. She proposes seven factors of cultural influence, including legacy, image and the presence effect. In their turn the include components of artistic culture such as painting, architecture, sculpture, cinema, literature, etc. All these phenomena contain the ideas and problems of the time, features of national cultures.

This soft power favours construction of images, constants and concepts in a cultural space through preservation of national traditions and customs and its transmission to spectators via works of art and culture (Bell, 2015; Fraser, 2015; Koptseva \& Kirko, 2014b; Lam, 2007; Libakova et al., 2014; Nye, 1990; Yang, 2015, etc)

\section{The influence of the concept Motherland on the formation of the types of Russian identities through cultural policy}

One of the examples of something on the one hand very simple, intelligible and eternal and on the other hand very complex, connected with socialization, legitimization and basic notions is the Motherland concept. It seems that the image of a native country, homeland, motherland or fatherland accompanies Russian people from their babyhood.

However, in his research on the process of formation of an image in general (taking the formation of the Motherland concept as an example) A.I. Shcherbinin took the notice of the fact that "if the mass of journalistic and patriotic texts is eliminated, the image of Motherland is not paid much attention" (Shcherbinin, 2009). The concept Motherland includes the idea of soul and it cannot be analyzed with the only power of reason. Adopted values and peculiarities of your Motherland and realization of the uniqueness of the place of birth and living form an image of a small homeland which can significantly influence a person's identity (Barrington et al., 2003; Weil et al., 2000). 
Such notions as Motherland, Fatherland, small homeland refer to the highest human values and form a powerful image which embodies cultural meanings and is able to influence the formation of one's value worldview. The concept of the small land, which from the geographical point of view is usually referred to a home town, a village or a territory, is closely connected with the phenomenon of regional identity as the place where a person was born and lived his or her life evokes the most intimate feelings which connect the Motherland and home. It is the matter of future researches to find out how the attitude of Russian people, residents of the Krasnoyarsk territory, to their Motherland is formed and how this image and the sense of belonging to a certain ethnic group influences the formation of the region identity of a Siberian.

The authors of a number of researches on the peculiarities of regional identities of the Krasnoyarsk city and the Krasnoyarsk territory residents use a concept called Siberian identity (Anisimova \& Echevskaya, 2012; Koptseva, 2014b; Reznikova, 2013; Shvetsov, 2013; Sunderland, 1996). That means our territory is rich with certain distinctive features which contain ethnic peculiarities inherent in our territory and demonstrated in all spheres of public and cultural life what allows to call its residents the Siberians and the very territory a part of immense Siberia. According to some points of view regional identity is the systematic totality of cultural relations connected with the small homeland concept and is a form of cultural enrootment. On the one hand the basis of the regional identity is founded on the natural necessity of human beings to obtain their own space (a certain plot of land), on the other hand the significance of the sense of belonging to a specific culture should not be underestimated.

The problem of the local mentality of the Russian people of Siberia has been in the focus of interest of historians, ethnologists, sociologists, philologists and students of local lore for many years.

The article "Siberian: community, nation or a state of soul?" is devoted to revelation and description of the key features of the Siberian identity and the basic regional components. That creates the necessary prerequisites for realization of the nature of our small homeland. "Today the issue of the Siberian identity is getting more relevant with the increase of regional consciousness in Russia in general and in the Siberian region in particular. It reveals in more and more active assumptions of residents of the regions to draw attention of the centre to their social-economic and ecological problems, in realization of regional cultural peculiarities, in increase of interest in the history of their region" (Anisimova \& Echevskaya, 2012).

Territorial and spatial prerequisites influencing the Siberian identity formation, which were traced in this article through interviewing residents of several Siberian cities (Novosibirsk, Omsk, Irkutsk), allow to found a certain ground to understanding the small homeland image formation for the residents of the Krasnoyarsk territory. The prerequisites are listed below:

1) Life in specific climatic conditions. Our unique nature and severe climate significantly contribute to the formation of the residents' special perception and attitude to their native land: carefulness towards nature, realization of the severity of the climate, which according to a number of interviewees inevitably hardens a persons, makes him or her more stable and patient;

2) Space and experience of developing it and living in it. Vast open space and non-uniformity of its development: "Detachment, remoteness, singularity of Siberia can be interpreted by informants both as a civilizational difference from the Western regions of the country and 
remoteness from the centre and its influence" (Anisimova \& Echevskaya, 2012);

3) Considering native land the basic value. "The Siberians consider the land to be not an economic resource, not a storage for treasures of soil, but to be of certain value itself" (Anisimova \& Echevskaya, 2012);

4) Not indifferent, not a consumer attitude towards native land in this case is the crucial point in the way of how the Siberians treat their homeland.

The problem of patriotic consciousness today is in the focus of scientific attention of sociologists, historians, political scientists who in particular study consciousness of young citizens of our country. Looking at the Motherland concept through the prism of its influence on young people seems indicative as far as youth is a good time for cultivating patriotic feelings what gives more opportunities for getting new information about current cultural situation. In the course of an associative experiment (Kolesnik, 2014), where the students of the Siberian Federal University (Krasnoyarsk) were involved, the meanings which the youth refers to the Motherland concept were detected. Following words were chosen as stimulus for the experiment: Russia, Motherland, Siberia, Siberian flavour, Siberian scent. Basing on the received data scientists drew a conclusion that the image of the Motherland from the youth's point of view is mainly positive. "The crucial aspect of understanding the Motherland concept is its perception as a state, a form of society organization with all necessary attributes, political and social institutions and official symbols. In this case the majority of the interviewees hearing the word Motherland think exactly of Russia and what is more they refer both to the attributes of the Russian Federation and Soviet Union" (Kolesnik, 2014). The results of the experiment allow to say that the Motherland concept in the minds of young people involve references to a general
Russian identity, belonging to a community which distinctive feature are friendly co-living, relevance of mutual historical values and irrelevance of racial and religious peculiarities. In its turn regional identity is determined by belonging to certain place and culture.

The results of another social research on ethic peculiarities of the self-consciousness of the Krasnoyarsk Siberians were presented in "Siberian (male and female) in Krasnoyarsk students' linguistic consciousness" (Felde, 2009). Here the emphasize is on ethnic selfconsciousness and it contributes to the formation of the certain image of the Motherland for the residents of the Krasnoyarsk territory. "Emotional and evaluative opinion of an ethnic unity about itself (i.e. ethnic autostereotypes) is the most important component of the mental sphere. As the result of analysis of emotional and evaluative opinions of what people consider their we can obtain objective data about the peculiarities of the conceptual sphere of a nation or a local ethnic group, we can come closer to understanding their mental features" (Kopnina, 2009). People who took part in the research were students of three Krasnoyarsk institutes of higher education: Siberian federal university, Krasnoyarsk state pedagogical university and Siberian institute of business, management and psychology. The students were the thirdfourth generation Siberians born in Russian or Russian-speaking mixed families. Analysis of the questionnaires showed that the image of Siberia and the associations mentioned by the respondents have mainly positive character. Distinctive features describing a Siberian include attachment to the native land, openness, friendliness, strength and bravery, ability to overcome difficulties and ordeals, unshakable love for the severe native land, image of a Siberian man as a true man who disdains frost and obstacles, image of a Siberian woman as 
a true Russian woman, a purposeful thrifty housewife with great strength of mind.

Thus a lot of scientists are interested in the ways of formation of different types of identities. The Motherland concept can contribute to the search for peculiarities of every type of identity (national, ethnic, territorial, regional, political). Even people of different countries have much in common when it comes to the Motherland as a word and image.

"Motherland is one of the most interesting cultural concepts, it exists in every ethnic culture and it is universal" - wrote M.G. Certcevadze in his article devoted to revealing the common to all mankind value of the Motherland concept in differently structured languages (Certsvadze, 2014).

In his article the author focuses on revealing similarities and differences between Russian and Georgian linguistic consciousnesses as referred to the Motherland conceptual sphere, he also carries out an associative experiment. His conclusion it that the given concept is one of the most significant cultural, mental, linguistic and spatial constants which form the Russian and Georgian world views. Moreover, the results of the associative experiment revealed close semantic relations between Russian and Georgian images of Motherland what confirmed the status of the given concept as a universal to whole mankind (Koptseva \& Reznikova, 2014).

The Motherland concept and its image as a mother of land have always been closely connected with the Russian mentality. "Mentality is peculiar memory of a nation about its past; history on the one hand is historical evidence, on the other hand historical fiction, it is special correction of the past: it should have been that instead of it was that" (Bagicheva, 2008).

Uniqueness of our Siberian land creates prerequisites to the formation of a special attitude to the image of our small homeland.
A.E. Zainutdinov, the author of an article devoted to the problems of regional development of Siberia, examines the history of the Siberian regional identity studying the contribution to this process made by a famous public figure and a publicist of the 60s, M.N. Yadrincev (Zainutdinov, 2014).

Special place in Yadrincev's intellectual heritage is assigned to civilisational ideas. Yadrincev devoted much attention to the place and part of Siberia in global civilisational processes and his ideas were closely connected with the Eurasian thought. For instance, Yadrincev appreciated the contribution of Eurasian nomadic folks to the development of civilization not only in Russia but also in the whole world: "According to N.M. Yadrincev, peculiarity of Siberia consists in the fact that its way is not exactly western or eastern. Unlike other colonies, Siberia has a unique geographical location (between the East and the West, between Asia and Europe) which determines its future part in the global civilisational process. This specific position determines status of Siberia as a veritable place where two civilizations meet. It is exactly the territory of Siberia where synthesis of two forms of civilasitional development truly takes place, that means that Siberia has significance for the whole mankind..." (Zainutdinov, 2014). Thus the most important part of the Siberian peculiarity or identity is its geopolitical location. Another significant component is ethnic. The territory of Siberia was the place where Russian people had intermingled with the aboriginal ethnic groups, that is a major distinctive feature of the Siberian identity.

Social processes are closely connected with culture and its artistic aspects. It has been already mentioned that artistic culture and creative work have a great influence on the process of identity formation, regional identity in particular. Residents of Siberian cities are not the exception. 
Thus modern artistic culture is characterized by global spread of the western artistic products and creation of works of mass artistic culture in many countries along with active development of original national cultural forms and undying interest of artists and audience to traditional themes, original styles, genres and arts. As before, modern artistic culture reflects classical images of the Russian way of life and unique Russian nature is still one of the most popular subjects for artists.

Modern Siberian artists tend to show inherent in Russian people traditions, customs and way of life through modern styles and genres of visual art (pop-art, poor art), through symbolism and confrontation of our and foreign cultures and through using new techniques and materials. Everything mentioned above allows to form certain artistic image of our small homeland, involving the audience into the process of artistic cognition and influencing their regional identity. An example of such influence is an exhibition project called the United States of Siberia (20122013). Candidate of Philosophical Sciences D.V. Galkin, who based his research on the project, in his article "Disposition of view or identity optics in modern art" expresses his opinion that the works of the artist, who participated in the project, contributed to the formation of the optics of the Siberian identity (Galkin, 2014). The given exhibition project involved the most famous modern Siberian artists: V. Slonov, K. Eremenko, D. Muratov, etc. The works of Vasili Slonov are the mix the Siberian view, slightly spiteful humour and rather rough irony, overall distrust of official symbols and any display of officialism his distrustful eye quickly and with inherent humour reveals any double-dealing. Konstantin Eremenko stylizes his aerographs into old photos. Sergey Bespamyatnih plays with the iconic status of the ancient Siberian land in a similar way. "The opinion of the residents of the art-republic of the
United States of Siberia modern Siberian identity is a blend of a rude and humoristic, grim and merry view of life, aggressive and buoyant separation from dominating American pop-culture and national pop-glamour, new revelation of Siberian as poor in the terms of a new cultural concept which in particular presupposes considerable distance between itself and national culture in any of its forms. It is the view where modern Siberian artists strive to entice us" (Galkin, 2014).

One more example of how artistic culture influences the formation of regional and national identity is the following research. In her article "Russian national identity among the youth" O.O. Namlinskya describes the results of a research carried out by the Institute of Humanities Research of the Moscow University of Humanities. Founders of the contest supposed that the contest "will reveal the views of a new generation brought up in the post-Soviet time about their Motherland and the destiny of Russian people, show the degree of popular mass culture influence on the society's consciousness". The results of the research allow to conclude that one of the crucial points of national identity for young people is Russian culture. The essays revealed admiration of great people who glorified their country: writers, poets, artists. It indicates great influence of artistic culture on the audience's consciousness and its ability to form attitudes to their Motherland. "Only spiritual things can now save Russian people. Today only when you understand literature, history and art in complex, see the value of original Russian culture, you can consider yourself Russian in full measure" (Oksana Z., Kalmykia republic)..." (Namlinskaya, 2006).

\section{Conclusion}

Summing up everything written above, the conclusion is that regional identity and its formation as other types of identity (national, ethnic, individual) today are the crucial issues 
which scientists examine from different points of view. National identity can only exist on the basis of social policy connected with the design of a national ideology through cultural policy with regional identities obtaining their new forms and emotional features. Soft power of cultural policy and smart power of scientific research can significantly influence the process of regional identity formation. The processes of national identity formation take place in many spheres especially in the sphere of artistic culture which is one of the keys to this issue. Soft power of art favours construction of images, constants and concepts in a cultural space through preservation of national traditions and customs and its transmission to spectators via works of art and culture. Motherland is a basic concept which is not only eternal, simple and understandable to everyone, but it also requires deeper research into the mechanisms of its influence on the Krasnoyarsk regional culture formation. Forming the image of our small homeland, the Krasnoyarsk territory as a part of immense Siberia, modern scientists and men of art create the basis for realization of value and uniqueness of all aspects of our Motherland by the residents of the Krasnoyarsk territory.

\section{References}

Alekhina, S. N. \& Kargapolova, E. V. (2010). The Social-culture Images of Home in the Mentality of Contemporary Russian Young People. Scientific Statements. Series Philosophy. Sociology. Law, 20 (19), 186-195.

Anisimova, A. A. \& Echevskaya, O. G. (2012). «Sibiryak»: Community, Nationality or «State of Mind»? Laboratorium. The Journal of Social Researches, 3, 11-41.

Antonova, M. S. (2010). The Cultural Policy in the Context of Regional Polyethnicity, The Works of St. Petersburg State University of Culture and Arts, 190, 116-122.

Assmann, J., \& Czaplicka, J. (1995). Collective memory and cultural identity.New German Critique, 125-133.

Bagicheva, N. V. (2008) The Image of Motherland in the Russian National Mentality. Cultural Linguistics, 2, 33-38.

Barrington, L. W., Herron, E. S., \& Silver, B. D. (2003). The motherland is calling: Views of homeland among Russians in the near abroad. World Politics, 55(02), 290-313.

Bell, E. (2015). Soft Power and Freedom Under the Coalition: State-corporate Power and the Threat to Democracy. Palgrave Macmillan.

Brace, C. (1999). Finding England Everywhere: Regional Identity and the Construction of National Identity, 1890-1940. Cultural Geographies, 6, (1), 90-109.

Brejda, J. J., Moorman, T. B., Karlen, D. L., \& Dao, T. H. (2000). Identification of regional soil quality factors and indicators I. Central and Southern High Plains.Soil Science Society of America Journal, 64(6), 2115-2124.

Certsvadze, M. G. (2014). The Concept of «Homeland» in a Different System Languages. Bulletin of Chelyabinsk State University, 7(336), 217-220.

Cheng, W., Liu, J., Yoshida, H., Rosen, D., \& Naora, H. (2005). Lineage infidelity of epithelial ovarian cancers is controlled by HOX genes that specify regional identity in the reproductive tract. Nature medicine, 11(5), 531-537.

Collier, M. J., \& Thomas, M. (1988). Cultural identity: An interpretive perspective. Theories in intercultural communication, 99, 122. 
Drozdova, M. V. (2011). Ethnicity as a Factor of Identification of a Person. Scientific notes of Taurida National University named after V. I. Vernadsky. Series «Philosophy. Culturology. Political science. Sociology», 26 (3-4), 272-277.

Dugin, A. G. (2010). Logos and Mythos. Sociology of the depth. Moskow, Academic project; Triksta.

Dugin, A. G. (2011). Ethnosociology. Moskow, Academic project.

Esmurzaeva, Zh. B. (2010). Value Component of Lexica-semantic Field of the Concept Motherland (According to the Research Findings). Bulletin of Omsk state University, 4, 199-204.

Felde, O.V. (2009). Sibirak in language consciousness of Krasnoyarsk students. Krasnoyarsk, publishing Siberian Federal University.

Fraser, M. (2015). American Pop Culture as Soft Power. Soft Power Superpowers, 172.

Friedman, J. (1994). Cultural identity and global process. Sage.

Galkin, D. V. (2013). Against Glamour Technology: Liberation of the Outlook for Contemporary Siberian Art. Tomsk State University Journal, 377, 53-57.

Gerasimov, A. S. (2013). Approaches to the Research of the Regional Identity in Russian Science. Bulletin of Pskov state University. Series «Natural, Physical and Mathematical Science», 3, 57-63.

Grossberg, L. (1996). Identity and cultural studies: Is that all there is. Questions of cultural identity, 87-107.

Guzenina, S. V. (2012). Phenomenon of the Motherland in the Collective Consciousness of Primitive and Ancient Societies. Historical and Social-education Idea, 3(13), 187-190.

Hall, S., \& Du Gay, P. (Eds.). (1996). Questions of Cultural Identity: SAGE Publications. Sage.

Il'beykina, M.I., Kolesnik, M.A., Libakova, N.M., Sertakova, E.A., \& Sitnikova, A.A. (2015). Global and local trends in development of the Siberian city Krasnoyarsk. Mediterranean Journal of Social Sciences, 6 (3), 241-248.

Khil'ko, N. F. (2014). Localization of Mechanism of National-Cultural Identity in Folk Traditions of Russians. Culture and Art, 3, $300-306$.

Khrapova, A. V. (2011). Towards Regional Identity. Social Philosophy and Problem of Integration. Science Journal Volgograd State University. Philosophy, 2 (14), 90-95.

Kistova, A., Pimenova, N., Zamaraeva, J., \& Reznikova, K. (2014a). Research possibilities for studying the indicators of quality of life of indigenous peoples of the North (based on the study of indigenous peoples of the North of Russia). Life Science Journal, 11(6s).

Kolesnik M. A. (2014). Specificity by All-national and Regional Cultural Identity of the Siberian Federal University Students on the Basis of Associative Experiment with the Word «Motherland». Modern Problems of Science and Education, 4, 595.

Kopnina, G.A. (2009). The theory of rhetorical device: the birth and development. Krasnoyarsk, publishing Siberian Federal University.

Koptseva, N. P., \& Kirko, V. (2014a). 'Ethnic identification of Indigenous People of the Siberian Arctic', American Journal of Applied Sciences, 11(9), 1574-1578.

Koptseva, N. P., \& Kirko, V. I. (2014b). The information basis for formation of positive ethnic identities in the process of acculturation of indigenous peoples of the Arctic Siberia (Krasnoyarsk, Russia). Life Science Journal, 11(8). 
Koptseva, N. P., \& Kirko, V. I. (2015). The Impact of Global Transformations on the Processes of Regional and Ethnic Identity of Indigenous Peoples Siberian Arctic. Mediterranean Journal of Social Sciences, 6(3 S5), 217-223.

Koptseva, N. P. \& Reznikova, K.V. (2014). To the Question of Cultural and Psychological Factors of National Security. The Results of Associative Experiment with Associate "Modern Warfare" (Based on Research done in Student Groups of the Siberian Federal University). National Security. Nota Bene, $5,791-815$.

Koptseva, N. P. (2014a). Expert analysis of the main trends of Northern Siberia's Indigenous small-numbered peoples economic development. Економічний часопис-XXI, (Economic Annals Journal-XXI), 11-12, 93-96.

Koptseva, N.P. (2014b). On the Question about Conceptual Grounds of Construction of the Russian National State. Issues of Society and Politics., 1, 1-14, doi: 10.7256/2306-0158.2014.1.10928

Lam, P. E. (2007). Japan's quest for "soft power": attraction and limitation. East Asia, 24(4), 349-363.

Libakova, N. M., Sitnikova, A.A., Sertakova, E.A., Kolesnik M.A., \& Ilbeykina M.I. (2014). Interaction of the Yakut ethnicity and biological systems in the territory of the Sakha Republic (Hordogoy settlement, Suntarsky District) and Krasnoyarsk Krai (Essey settlement, Evenks District), Life Science, 11(6s), 585-592.

Mansurov, T. Z. (2011). Theoretical and Methodological Approaches to the Problem of Regional Identity in Political Science. Uchenye zapiski Kazanskogo universiteta, 153 (1), 181-190.

Namlinskaya, O. O. (2006). Russian National Identity Among the Young People. Knowledge. Understanding. Skill, 2, 211-218.

Nye, J. S. (1990). Soft power. Foreign policy, 153-171.

Novikova, M. A. (2006). The Small Homeland, the Great Motherland (Concepts in the Translation of Texts of Patriotic Discourse). Scientific Notes of Taurida national University named after V. I. Vernadsky. Series «Philosophy», 19 (2), 51-53.

Paasi, A. (2003). Region and place: regional identity in question. Progress in Human Geography, 27 (4), 475-485.

Paasi, A. (2013). The institutionalization of regions: a theoretical framework for understanding the emergence of regions and the constitution of regional identity. Fennia-International Journal of Geography, 164(1), 105-146.

Prokkola, E. K., Zimmerbauer, K., \& Jakola, F. (2015). Performance of regional identity in the implementation of European cross-border initiatives. European Urban and Regional Studies, 22(1), 104-117.

Raagmaa, G. (2002). Regional identity in regional development and Planning1. European Planning Studies, 10(1), 55-76.

Reznikova, K.V. (2013). The importance of cinema for the formation of Russian national identity. Modern Problems of Science and Education, 3, Available at: http://www.scienceeducation.ru/1099580

Sunderland, W. (1996). Russians into Iakuts?" Going Native” and Problems of Russian National Identity in the Siberian North, 1870s-1914. Slavic Review, 806-825.

Santos, S. C. (2015). Identity in Mercosur: Regionalism and Nationalism. Global Governance: A Review of Multilateralism and International Organizations, 21(1), 43-59. 
Shcherbinin, A. I. (2009). The Creation of the Image (on the Material of the Creation of Concept «Motherland»). Art Marketing, 4(28), 19-27.

Shevtsov, V. V. (2013). The regional identity of the Siberian community: major formation factors and reconstruction problems. Europolis, Journal of Political Science And Theory, (7 (1), 77-93.

Shusharina, G. A. (2013). Ways of and Methods for Shaping Regional Cultural Identity Using Local Mass Media Channels' Potentials. Researches of Komsomolsk-on-Amur State Technical University, 112(14), 51-55.

Sitnikova, A. A. (2014). The Concept of "North" in the Works by Rockwell Kent. Cultures and Arts, 2, 1-27, doi: 10.7256/2306-1618.2014.2.11550

Smolicz, J. (1981). Core values and cultural identity. Ethnic and racial studies,4(1), 75-90.

Szabo, A., \& Ward, C. (2015). Identity development during cultural transition: The role of socialcognitive identity processes. International Journal of Intercultural Relations, 46, 13-25.

Terada, T. (2003). Constructing an 'East Asian'concept and growing regional identity: from EAEC to ASEAN+3. The Pacific Review, 16(2), 251-277.

Ting-Toomey, S., Yee-Jung, K. K., Shapiro, R. B., Garcia, W., Wright, T. J., \& Oetzel, J. G. (2000). Ethnic/cultural identity salience and conflict styles in four US ethnic groups. International Journal of Intercultural Relations, 24(1), 47-81.

The New Future of Siberia: Expectations, Provocations, Solutions. (2013). Ed. by Natalia Koptseva. Krasnoyarsk, Siberian Federal University.

The Theory and Practice of Applied Cultural Studies: regional project. (2013). Ed. by Natalia Koptseva. St. Petersburg, Eidos.

Ward, C., \& Searle, W. (1991). The impact of value discrepancies and cultural identity on psychological and sociocultural adjustment of sojourners. International Journal of Intercultural Relations, 15(2), 209-224.

Weil, S., Anteby, L., Berthomiere, W., \& Sheffer, G. (2000). Motherland and fatherland as dichotomous diasporas: the case of the Bene Israel. Les Diasporas, 91-99.

Wrobel, D. M. \& Steiner, M. C. (1997). Many Wests: Place, Culture \& Regional Identity. Univ Pr of Kansas.

Yadov, V. A. (1995). Social and Socio-psychological Mechanisms of Formation of Social Identity. Modern Situation in Russia. World Russia, 3-4, 158-181.

Yang, R. (2015). China's soft power projection in higher education. International Higher Education, (46).

Zainutdinov, A. E. (2014). Siberian Regionalism of N. M. Jadrintsev in the Context of Glocalization. Sociology of Science and Technology, 2 (5), 164-171.

Zamarayeva Y.S., Kistova A.V., Reznikova K.V., Pimenova N.N., Seredkina N.N. (2015). Taymyr reindeer herding as a branch of the economy and a fundamental social identification practice for indigenous peoples of the Siberian Arctic. Mediterranean Journal of Social Sciences, 6 (3), 225-232.

Zvyagina, D. A. (2012). Cultural Influence as Component of «Soft Power». Historical, Philosophical, Political and Law Sciences, Culturology and Study of Art. Issues of Theory and Practice. Gramota, 11 (25), 94-98. 


\title{
Становление региональной идентичности \\ в пространстве Сибирского региона \\ (на материале анализа концепта «Родина»)
}

\author{
А.М. Обморокова, Н.О. Немаева \\ Сибирский федеральный университет \\ Россия, 660041, Красноярск, пр. Свободный, 79
}

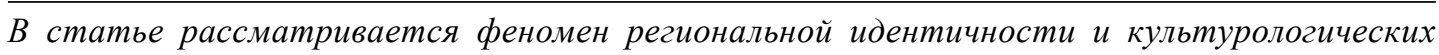
особенностей её формирования. Ключом к пониманию прочессов формирования различньх видов идентичностей является изучение начиональных и этнических культурных прочессов. В статье затронут аспект влияния этнокультурной идентичности на формирование национального самосознания и проведен краткий аналитический обзор научных работ других авторов по теме исследования. В современном мире значительную роль в становлении региональной идентичности и самоидентификации играет «мягкая сила» культурной политики и «умная сила» научных исследований, деятельность творческих акторов и ученьх, живущих и работающих в конкретном регионе. Применение подобных видов деятельности помогает конструировать образы, константы и кониепты в культурном пространстве региона, которые участвуют в прочессе сохранения национальных традиций и обычаев и передачи их через произведения культуры и искусства зрителю. Одним из примеров такого концепта, связанного с социализацией, признанием и базовыми смыслами, взят концепт «Родина». Рассматривается образ малой родины в сознании жителя Сибирского региона.

Ключевые слова: региональная идентичность, этничность, национальное самосознание, Родина, Сибирь, концепт, художественная культура.

Научная специальность: 24.00.00-культурология. 